\title{
PENGARUH KESADARAN METAKOGNISI TERHADAP PRESTASI AKADEMIK MAHASISWA FMIPA UNIVERSITAS SULAWESI BARAT
}

Oleh:

Sitti Inaya Masrura, S.Pd., M.Pd

Dosen Pendidikan Matematika FMIPA Universitas Sulawesi Barat

Email: Sittiinayamasrura@unsulbar.ac.id

\begin{abstract}
This study aims to determine the effect of metacognition awareness on the academic achievement of FMIPA students of the University of West Sulawesi. This type of research is expost-facto research that is causality. The population of this study is the students of the Faculty of Mathematics and Natural Sciences of the university of West Sulawesi in 2016 as many as 301 people with a total sample of 172. Sampling technique using proportionate stratified random sampling. Data collection was done by using, questioner, and data of student achievement. Data were analyzed by descriptive statistic and inferential analysis using linear regression. The result of the research shows that: (1) Most of FMIPA university students of West Sulawesi have metacognition awareness which is in high category, (2) Metacognition awareness has positive and significant impact to student achievement
\end{abstract}

Keyword: Metacognition awareness, academic achievement

\begin{abstract}
Abstak
Penelitian ini bertujuan untuk mengetahui pengaruh kesadaran metakognisi terhadap prestasi akademik mahasiswa FMIPA Universitas Sulawesi Barat. Jenis penelitian ini adalah penelitian expost-facto yang bersifat kausalitas. Populasi penelitian ini adalah mahasiswa FMIPA universitas Sulawesi Barat Angkatan 2016 sebanyak 301 orang dengan jumlah sampel sebanyak 172. Teknik pengambilan sampel dengan menggunakan proportionate stratified random sampling. Pengumpulan data dilakukan dengan mengunakan, kuesioner, dan data prestasi akademik mahasiswa. Data dianalisis dengan statisik deskriptif dan analisis inferensial menggunakan Regresi linier. Hasil Penelitian menunjukkan bahwa: (1) Sebagian besar mahasiswa FMIPA universitas Sulawesi Barat memiliki kesadaran metakognisi yang berada pada kategori tinggi, (2) Kesadaran metakognisi berpengaruh positif dan signifikan terhadap prestasi akademik mahasiswa
\end{abstract}

Kata kunci: Kesadaran metakognisi, prestasi akademik.

\section{PENDAHULUAN}

Pada jenjang perguruan tinggi indikator keberhasilan seorang mahasiswa, dapat diketahui dengan melihat nilai indeks prestasi (IP). Indeks prestasi (IP) adalah nilai kredit rata-rata yang merupakan satuan nilai akhir yang menggambarkan nilai proses belajar tiap semester atau dapat diartikan juga sebagai besaran atau angka yang menyatakan prestasi keberhasilan dalam proses belajar mahasiswa pada satu semester. Mahasiswa yang memperoleh indeks prestasi tinggi mengindikasikan bahwa mahasiswa tersebut mampu mengikuti kuliah dengan baik dan sebaliknya semakin rendah indeks prestasi yang diperoleh menunjukkan bahwa mahasiswa tersebut tidak mampu 
mengikuti kuliah dengan baik. (Daely et al, 2013)

Prestasi akademik mahasiswa FMIPA Universitas Sulawesi Barat masih tergolong rendah seperti minimnya prestasi yang di raih dalam kompetisi sains nasional, di bidang matematika, fisika, kimia dan rumpun MIPA lainnya. Pada tahun 2015 lalu dari kompetisi OSN pertamina hanya 1 mahasiswa dari fisika saja yang bisa lolos ke tingkat nasional. Meskipun kenyataannya seperti itu hal ini merupakan penyemangat untuk meraih prestasi yang lebih baik lagi ( Muhtar \& Arafah, 2015)

Pada umumnya prestasi belajar siswa di indonesia masih lebih banyak diukur berdasarkan kemampuan kognitifnya. Oleh karena itu perlu diperhatikan tentang perkembangan struktur kognitifnya, salah satu penentunya adalah strategi kognitif yang merupakan keterampilan intelektual khusus yang sangat penting di dalam belajar dan berpikir (Muisman, 2003). Strategi kognitif yang dimaksud adalah salah satu dari kemampuan metakognitif.

Metakognisi adalah kemampuan berpikir di mana yang menjadi objek berpikirnya adalah proses berpikir yang terjadi pada diri sendiri. Dalam konteks pembelajaran, peserta didik mengetahui bagaimana untuk belajar (learning how to learn), dan mengetahui strategi belajar terbaik untuk belajar efektif. Metakognisi sebagai suatu bentuk kemampuan untuk melihat pada diri sendiri sehingga apa yang dia lakukan dapat terkontrol secara optimal (Sastrawati, et al, 2011). Keberhasilan seseorang dalam belajar dipengaruhi oleh kemampuan metakognitifnya. Jika setiap kegiatan belajar dilakukan dengan mengacu pada indikator dari learning how to learn maka hasil optimal pasti akan mudah dicapai (Yustina \& Bambang, 2012). Untuk mendapatkan kemampuan metakognitif terlebih dahulu harus memiliki kesadaran metakognitif.

Berdasarkan uraian diatas maka timbul gagasan untuk meneliti tentang apakah ada Pengaruh Kesadaran metakognisi terhadap Pestasi Akademik Mahasiswa FMIPA Universitas Sulawesi Barat.

\section{METODE}

Penelitian ini termasuk penelitian expost facto yang bertujuan untuk mengetahui pengaruh Kesadaran metakognisi dan motivasi belajar matemaatika terhadap prestasi akademik mahasiswa FMIPA Universitas Sulawesi Barat. Penelitian ini terdiri atas dua variabel, yaitu variabel terikat dan variabel bebas. Variabel terikat dalam penelitian ini yaitu prestasi akademik (Y).Variabel bebas yaitu 
Kesadaran Metakognisi mahasiswa (X). Dapat digambarkan sebagai berikut:

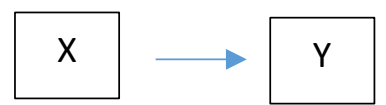

Adapun definisi operasional variabelnya adalah sebagai berikut:

a) Kesadaran Metakognisi (X) adalah kesadaran berpikir mahasiswa tentang proses berpikirnya sendiri yang berkaitan dengan proses belajar matematika.

b) Prestasi Akademik (Y) adalah berdasarkan IP (Indeks Prestasi) mahasiswa angkatan 2016 Fakultas Matematika dan Ilmu Pengetahuan Alam Universitas Sulawesi Barat.

Populasi penelitian ini adalah mahasiswa FMIPA universitas Sulawesi Barat Angkatan 2016 sebanyak 301 orang dengan jumlah sampel sebanyak 172. Teknik pengambilan sampel dengan menggunakan proportionate stratified random sampling. Pengumpulan data dilakukan dengan mengunakan, kuesioner, dan data prestasi akademik mahasiswa.

Variabel kesadaran metakognisi dikategorikan berdasarkan lima kategori skor yang dikembangkan dalam skala likert dan digunakan dalam penelitian ini. Adapun kriteria yang dimaksud adalah sebagai berikut:

\begin{tabular}{c|c}
\hline Kriteria & Skor \\
\hline Sangat Rendah & $30 \leq \mathrm{KM}<48$ \\
Rendah & $48 \leq \mathrm{KM}<66$ \\
Sedang & $66 \leq \mathrm{KM}<84$ \\
Tinggi & $84 \leq \mathrm{KM}<102$ \\
Sangat Tinggi & $102 \leq \mathrm{KM} \leq 120$ \\
\hline
\end{tabular}

\section{HASIL DAN PEMBAHASAN}

Hasil analisis deskriptif menunjukkan bahwa rata-rata skor kesadaran metakognisi mahasiswa adalah 90,69. Berdasarkan data hasil analisis tersebut secara umum dapat disimpulkan bahwa kesadaran metakognisi yang dimiliki oleh mahasiswa FMIPA universitas Sulawesi Barat berada dalam kategori tinggi. Adapun hasil pengkategoriannya dapat disajikan dalam diagram berikut: 


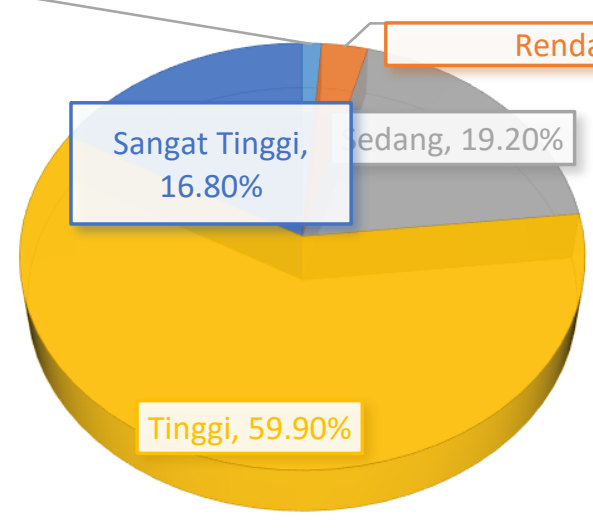

Hasil pengujian hipotesis dengan menggunakan analisis SPSS dengan taraf signifikansi 5\%, dapat dilihat dalam tabel berikut:

\section{Coefficients $^{\text {a }}$}

\begin{tabular}{|c|c|c|c|c|c|c|}
\hline \multirow{2}{*}{\multicolumn{2}{|c|}{ Model }} & \multicolumn{2}{|c|}{$\begin{array}{c}\text { Unstandardized } \\
\text { Coefficients }\end{array}$} & \multirow{2}{*}{$\begin{array}{l}\text { Standardized } \\
\text { Coefficients } \\
\text { Beta }\end{array}$} & \multirow[b]{2}{*}{$\mathrm{T}$} & \multirow[b]{2}{*}{ Sig. } \\
\hline & & B & Std. Error & & & \\
\hline \multirow[t]{3}{*}{1} & B & .450 & .116 & \multirow{3}{*}{.872} & 3.867 & \multirow{3}{*}{$\begin{array}{l}.000 \\
.000\end{array}$} \\
\hline & Kesadaran & .030 & .001 & & 23.279 & \\
\hline & Metakognisi & & & & & \\
\hline
\end{tabular}

a. Dependent Variable: Prestasi akademik 
Dari uji $\mathrm{t}$ dapat dilihat bahwa nilai signifikansi sebesar $0,000<0,05$. Sehingga dapat disimpulkan bahwa Ho ditolak berarti terdapat pengaruh yang signifikan dari variabel bebas kesadaran metakognisi terhadap prestasi akademik. Persamaan regresi yang diperoleh adalah $\mathrm{Y}=0,450$ $+0,030 \mathrm{X}$ dari persamaan tersebut dapat disimpulkan bahwa setiap 1 unit penambahan variabel bebas kesadaran metakognisi akan meningkatkan variabel terikat prestasi akademik sebesar 0,030.

Hal ini sesuai dengan teori-teori metakognisi yang membahas tentang metakognisi dan prestasi belajar siswa antara lain: Flavell (1979) merumuskan bahwa metakognisi memainkan peranan yang penting dalam pembelajaran. Begitu juga dengan Brown (1987) menyatakan bahwa pembelajaran yang aktif mergulasi dan memperbaiki tindakan mereka akan Livingstone, Jeniffer A.1997. memperbaiki hasil pembelajaran mereka. (Livingston, 1997). Lebih lanjut Rahman \& Philips (2006) menjelaskan dalam penelitiannya bahwa kesadaran metakognisi mempunyai hubungan langsung positif yang signifikan terhadap pencapaian akademik pelajar.

\section{Simpulan}

Hasil Penelitian menunjukkan bahwa: (1) Sebagian besar mahasiswa FMIPA universitas Sulawesi Barat memiliki kesadaran metakognisi yang berada pada kategori tinggi, (2) Kesadaran metakognisi berpengaruh positif dan signifikan terhadap prestasi akademik mahasiswa.

\section{Pustaka}

Daely, K. dan Manurung, U.S.A. 2013. Analisis Statistik Faktor-Faktor Yang Mempengaruhi Indeks Prestasi Mahasiswa. (Online). http://download.portalgaruda.org/article .php? article $=111024 \& v a l=4141$. Diakses tanggal 10 Mei 2016

Metacognition: An overview, (Online). (Http://www.gse.buffalo.edu/fas/shuell/ CEP564/metacog.html.). Diakses 15 Oktober 2010

Muhtar, A \& Arafah, M. 2015. Mahasiswi Unsulbar Ukir Prestasi. http://upeks.co.id/edukasibudaya/mahasiswi-unsulbar-ukirprestasi.html. Diakses tanggal 9 Juni 2016

Muisman. 2003. Analisis jalur Hasil Belajar Matapelajaran Ekonomi Berdasarkan Kecerdasan, strategi-strategi metakognitif Dan Pengetahuan Awal. Tesis. Tidak diterbitkan: IKIP Singaraja. 
Rahman S \& Philips J A, 2006. Hubungan antara metakognisi, motivasi dan pencapaian akademik Pelajar University. Jurnal pendidikan, 31, 2139.

Sastrawati Eka, et al. 2011. Problem-Based Learning, Strategi Metakognisi, dan
Keterampilan berpikir tingkat tinggi mahasiswa. Tekno-Pedagogi. 1. No 2

Yustina dan Bambang. 2012. Korelasi antara Keterampilan Metakognitif dengan Hasil Belajar Siswa di SMA 1 Dawarblandong Mojokerto, Journal of Chemical Education. Vol 2 hal:8 